\title{
Special Education in Brazil in the Early 20th Century: An Innovative Experience Inspired in New Education Ideals
}

\author{
Adriana Araújo Pereira Borges, Regina Helena de Freitas Campos \\ School of Education, Federal University of Minas, Belo Horizonte, Brazil \\ Email: adriana.borges@terra.com.br
}

Received 31 March 2016; accepted 21 May 2016; published 24 May 2016

Copyright $(\subset 2016$ by authors and Scientific Research Publishing Inc.

This work is licensed under the Creative Commons Attribution International License (CC BY). http://creativecommons.org/licenses/by/4.0/

(c) () Open Access

\section{Abstract}

In 1927, the Minas Gerais state government, in Brazil, published new Primary Education Regulations proposing that elementary school's classrooms be homogenized according to the intellectual level of students. In the following years, special classes were established, and initiatives for the education of abnormal children were performed at the Pestalozzi Society in Belo Horizonte, the capital of the State. The purpose of this paper is to explore the innovative character of these initiatives, using primary sources and publications of the time, including reports on the examination of children to be treated and educated. The research showed that Russian-Brazilian psychologist and educator Helena Antipoff (1892-1974) played an important role in developing an innovative model for special education in these institutions, based on her experience as a student and as a researcher at the Institute Jean Jacques Rousseau, in Geneva, and in Russia, during the troubled years of the Communist Revolution. At Pestalozzi Institute, a school for exceptional children, she established in Belo Horizonte during the 1930s, with the help of a group of teachers, physicians and philanthropists, and Antipoff used her rich multicultural background to design a specific methodology for the special classes, based on the ideals of the New School as well as on respect for children's rights.

\section{Keywords}

Special Class, Special Education, Rousseau Institute, Helena Antipoff

\section{Introduction}

In Brazil, in the state of Minas Gerais, there are records of children being admitted into psychiatric hospitals

How to cite this paper: Borges, A. A. P., \& de Freitas Campos, R. H. (2016). Special Education in Brazil in the Early 20th Century: An Innovative Experience Inspired in New Education Ideals. Creative Education, 7, 971-978. 
since 1827 (Cirino, 1992). Back then, in face of the vast conceptual diversity within the concept of abnormality, disabled children had no special care. This scenario starts to change after some specific proposals such as the construction of wings or pavilions at hospitals (the Bourrneville Pavilion in Rio de Janeiro) and schools located next to hospitals, as annexes (Escola Pacheco e Silva, at Hospital Juqueri, in São Paulo). But only after educational reforms made in several Brazilian states during the 1920s were disabled children allowed to access public schools, rather than being committed to psychiatric hospitals.

The educational reform implemented in the state of Minas Gerais in 1927-1928 invited Russian psychologist and educator Helena Antipoff (1894-1972) to teach educational psychology at a newly established Escola de Aperfeiçoamento de Professores (College for Teachers' Improvement), in the capital of the state, Belo Horizonte. In this position she initiated a sound research program on the mental development of local schoolchildren, published papers, fought for the rights of children and helped to write the history of education and psychology in the country. Her work in the field of special education, assisting, treating and educating disabled children, has opened new perspectives in the area. At the School's Laboratory of Psychology, one of the first labs of this type to be installed in Brazil, Antipoff and her students collaborated with the local educational system reform by encouraging the modernization of educational processes and methods, in addition to collecting data on psychological and psychosocial characteristics of children in Minas Gerais. They aimed at disseminating New Education methods and promoting more efficiency in educational practices (Campos, 2001, 2012).

The Psychology Laboratory played a vital role in the homogenization of elementary schools' classrooms according to the intellectual level of students. The idea was to separate children in different classes based on intelligence tests' results. Children with the best test scores should be assigned to the most advanced classes. Children who failed the tests stayed in lower level or special classes. Since the early 20th century this criterion for the organization of classrooms was being widely used in other countries in the world, considering individual differences that became clearer as the population massively entered public schools (Ruchat, 2003). In Minas Gerais, special classes began to be established in 1931, based on the work carried out at the Laboratory.

Classes were divided in each school, according to results obtained in IQ tests adapted to the local population. The classes with the students with the highest scores would be named using the first letter of the alphabet: A. B classes would receive children whose scores were slightly lower. $\mathrm{C}$ classes would be for children with up to three years of mental retardation, as well as children with "sleeping spirits, or turbulent, but with no noticeable physical or moral defects" (Antipoff, 1931). D classes received children with noticeable disabilities, physical or psychological extraordinary specificities and who needed special schooling conditions. These classes would be referred to as individual education classes. In addition, E classes were destined to children considered to present difficult behavior.

Individual differences within the class homogenization system in Minas Gerais were a concern for Antipoff. Teachers had little resources to deal with children scoring below average on intelligence tests. Therefore, even though the work conducted by the College for Teachers's Improvement was intense, it was not able to solve practical problems teachers began to face. Considering these dilemmas, Antipoff led a group of educators, physicians and philanthropists in the proposal to establish a non-profit organization to help teachers look for solutions to assist those exceptional children, as they started to be named. The institution was the Socieda de Pestalozzi de Minas Gerais (Minas Gerais Pestalozzi Society), which was chaired by Helena Antipoff from 1932 to 1945.

Pestalozzi Society established one of the first medical-pedagogical stations in the country and was a pioneer of multidisciplinary care, which included physicians, educators and psychologists. Pestalozzians also created an institution to help homeless children, many of whom sold newspapers in the streets. The institution offered housing, food and education to these children. A special school for retarded and abandoned children, also initiated by Pestalozzians, named Instituto Pestalozzi (Pestalozzi Institute), was built in 1935. There, special classes and special education methods were developed.

Our hypothesis is that the special classes implemented at Pestalozzi Institute in Belo Horizonte were an important example of knowledge circulation and of how culture absorbs and transforms concepts. Campos, Lourenço and Antonini (2002) argue that scientific activity has become a passport for many individuals going through the experience of moving through cultures, a common experience for many individuals during the first half of the 20th century, when European social crises came to pass. Helena Antipoff was born a Russian, but lived in France and was an intern at Alfred Binet and Theodore Simon's Laboratory. In Geneva, she was in the first class at Institute Jean Jacques Rousseau, one of the most important educators' training center at the time 
(Hofstetter \& Schnewly, 2009; Roca, 2012; Van Drenth \& Myers, 2011). Returning to Russia, in 1917, she worked in institutions for abandoned children during the troubled years of war and revolution. Returning to Geneva, she worked as Édouard Claparède's assistant at the Rousseau Institute, learning with her master, a progressive education leader, new educational methods and procedures. Her experience in Brazil, based on what she had learned in Europe, was an opportunity to create an innovative methodology in the care of disabled children.

\section{Methodology}

This study is based on unpublished documents and publications preserved at Helena Antipoff's archives, located at the Central Library of the Federal University of Minas Gerais, as well as on personal documents filed at the Helena Antipoff Documentation and Research Center (CDPHA), in the town of Ibirite, state of Minas Gerais, Brazil. Some of these records are unique and essential for this research, such as a collection of brochures published by the Minas Gerais Education and Public Health Department during the 1930s, when Pestalozzi Society and Pestalozzi Institute were established (Resende, 1934; Sociedade Pestalozzi, 1933). Also the Pestalozzi Society periodical Infância Excepcional (Exceptional Childhood), published between 1933 and 1937, is an important source for this research, especially the editions 12, 16 and 20 from 1933, 1934 and 1937, respectively (Minas Gerais 1933, 1934, 1937). These publications bring articles written by partners working at the Pestalozzi Society and Institute, in addition to reports on clinical appointments, assessment forms, that is, a rich material in terms of information.

Purposes and methods for the education of special classes at the time were extracted from these documents. Also, based on information found in medical and psychological reports filed at Pestalozzi Institute, we could collect records, fragments of the history of disabled children who attended the Institute's classes or were examined by its professional team on their physical and mental health, and also on their educational level. The guidelines provided by the team of professionals responsible for the care of these children were essential to recall extremely refined conducts for the time. Both these points were vital for this study to take place.

Overall, 80 medical and psychological reports made between 1933 and 1940 were selected and analysed, as we were interested in records of the beginnings of the Institute (established in 1935) and of its Medical-Pedagogical Station's practices, that started in 1933. The reports were found in Pestalozzi Institute's archives, organized in boxes by alphabetical order. Reports done within the period chosen were randomly picked up in each box. Information varied from one report to another. Some were more thorough, others did not have a lot of information. Our analysis focused on: 1) the criteria used to classify children according to their difficulties at school, and to their level of mental development; 2) the description of children's physical and psychological characteristics, and the relationship established between these characteristics and their possibilities in education and 3) procedures suggested for disabled children's special education. One of the reports caught our attention due to the thorough description of the procedures. This specific report referred to a boy who was a patient at Pestalozzi Institute in 1934. His examination was signed by Helena Antipoff herself, the professional who showed a deeper knowledge in the field of psychology among Pestalozzi professionals. Her students, educators trained at the Teachers' College, followed her directions in the examination of children and planning of their education. For these reasons, and to highlight the characteristics of the model proposed by Antipoff for children's examination and education, this report was chosen to be discussed later on in this paper.

Samara and Tupy (2007) propose that the contact with the written text must raise some questions for the researcher which are essential for the first approach. It is important to be aware of how the material is presented, its content, the objectives and purposes of the person who prepared that material, as well as those of who reads and interprets it. Then, a new way to look at special classes is proposed: a contextualized look, supported by the study of primary sources, thus showing how those special classes were innovative at that time.

\section{The Special Classes}

The division of special classes per school, proposed by Antipoff, was already innovative. The classes could be organized in specific areas of the city. Thus, a school could have a class which was exclusive for intellectually impaired children at a certain region of the city, whereas another school could have a class targeted at vision impairments, an-other one for motor impairments and so on (Antipoff, 1992). Besides the special classes located in public schools, two other classes were opened during the same period. In May, 1932, a class for children with 
abnormal behavior was opened next to the College for Teachers' Improvement, receiving 15 children with lethargic temperament and mental disability. In 1933, another class was opened next to the College, receiving 5 "deaf-mute" children three times a week. In these classes, new methods were experimented by teachers being trained there.

In 1933, Belo Horizonte already had 34 special classes in 15 different schools. Considering a total of 9,272 children, 883 children attended special classes, that is, 9.5\% of the population (Sociedade Pestalozzi, 1933). These classes were established by teachers trained at the College for Teachers' Improvement, considering test results and observations. Another criterion was whether the child failed the school year. In other words, if children had already failed a school year, they would probably be assigned to a special class.

As of May 1933, the Psychology Laboratory at the College began to provide guidance and material support to D classes in Belo Horizonte public schools. This work consisted of visiting elementary schools and gathering information about their physical conditions, number of students and the level of mental and social development of the students, assessed via Goodenough, Deaborn and Binet-Simon intelligence tests. It is important to stress that the de-nomination "D Class" meant a level of inferiority in mental level and academic performance of that class as compared to other classes within the same school. Therefore, different D classes could present very different mental levels, ac-cording to the social and economic level of families living in different areas of the city (Resende, 1934).

Another important point was the concern for the overall health of students. Studies were carried out to investigate cases of worm infections, which were very common, as the country lacked sanitation. In addition, heredo-lues cases were recorded in children, that is, cases of hereditary syphilis pointed out as the cause of children's intellectual impairment. There were also endocrinological studies, especially in relation to congenital hypothyroidism. The physician responsible for the schools states that there was a great difference between A Class and D Class children. Whereas A Class children had ruddy complexion and were hefty and smart, D Class children were lazy and had no energy. This observation shows how social class distances were already great at that time: on the one hand, children whose families lived with dignity, with access to sewage, a healthy diet, books and other goods; on the other hand, children who barely ate and lived in subhuman conditions.

Instead of accepting the easier explanation that D Class children did not learn because they were poor, Antipoff proposes a new concept: "civilized intelligence". Intelligence could not be limited to the realm of natural abilities; it would rather be a complex product which would include the environment, stimuli the child received and her access to cultural goods. Helena Antipoff expands the concept of intelligence. Children raised in an unfavorable environment, with no access to cultural goods, weakly stimulated, would present deficits in tests, even though they could have a natural intelligence. This means that they could not be considered mentally impaired, they simply did not have contact with the codes and tools which would allow them to perform well, whether in tests or in the school environment, which has its own codes of conduct. Mental tests would be important, but only to be used as guidelines of the types of educational resources needed so that children could learn. That being said, results could change as children were adequately stimulated.

Children in special classes could be given more time to acquire certain competences. Physical exercises, music lessons, gardening and mental orthopedics exercises were used to stimulate children. The field of "mental orthopedics" had been created in 1910 by Alfred Binet. The purpose of mental orthopedics exercises was to strengthen the mind, as an analogy with orthopedics, which attempts to correct body deformities. The systematic and repetitive training of mental functions is the basis of mental orthopedics exercises, which target the improvement of these functions. Binet assumes that if a muscle can improve its function with exercises, so can the mind. Education possibly could not create or enhance the potential of mental faculties, but it could organize these faculties, creating conditions for children to make better use of them.

The purpose of the exercises was to stimulate the sensory system and, thus, improve children's perception. Sensory organs would be exercised. The exercises aimed at improving the senses, enhancing perception. These exercises were prepared at the College Laboratory of Psychology and sent to teachers of special classes. Just like orthopedics meant to correct body deformities, mental orthopedics meant to stimulate and shape intelligence. In order to do that, it would be necessary to exercise several mental functions.

Even though there was a great effort to perform a different work with special classes, it was very hard to have any control over those teaching these classes. Despite the guidelines provided, many teachers did not apply the methodology. Helena Antipoff then proposed the creation of the Pestalozzi Institute. A special school where children could receive the differentiated education she advocated for. The Institute was created in 1935. 


\section{Instituto Pestalozzi (Pestalozzi Institute)}

Antipoff considered the Pestalozzi Institute a child of the Jean Jacques Rousseau Institute of Geneva. For her, this association was based on the philosophy of both institutes. Just like the Genevan institute, Pestalozzi Institute was intended to protect infancy, especially disabled children. Respect to human rights was key. Another assumption was the belief in human capacity under the most unfavorable circumstances. Children should be able to develop themselves, despite their limitations. The Institute was created to treat and educate a population of children who, up to that point, had not received adequate care; a population which had been committed to psychiatric hospitals, or which had been limited to their homes.

Right after it was opened in 1935, Pestalozzi Institute had 74 students enrolled. SPMG's Medical-Pedagogical Station, which had been opened since 1932, became part of the Institute. The institution offered treatment and education. Five classes were organized: Two for more serious or mild mental retardation, one for deaf-mute children and two for older boys with no mental impairment but who were retarded in school or had difficulties of a social nature (Antipoff, 1944). In 1936, the number of students reached 90. The Institute was equipped with several materials, such as Montessori, Asen, Décroly, in addition to educational games bought or made by its members. As the institution had no cleaning staff, the cleaning was done by children and teachers, as combined in their Saturday meetings. Classroom tasks, recreational reading, household chores, workshops, meetings with the principal, field trips: all activities were valued.

The Institute's greatest concern and purpose was to adapt children to the needs of economic and social life, allowing them to develop the necessary competences to be less dependent on others and live life with dignity. Children with mental level between 4 and 7 years of age should be encouraged to find a repetitive job, which is not interesting for most people but which is ideal for these children, as they do not get tired of doing the same thing over and over. Other children with limits higher than 12 years of age could be encouraged to find a job with more responsibility. It was pointed out, however, their lack the ability to intervene in an individual way, adequate to a new situation. Dignity was linked to the possibility of having a productive adult life.

In 1937, there were 137 children enrolled at the Pestalozzi Institute (Antipoff, 1944). In 1938, there were already 150 students (Antipoff, 1944a): one class for deaf children; six classes of children with mental ages between 2 and 13 and actual age between 7 and 16. Even though the initial proposal was to receive children that could be educated, since the beginning the Institute received children with more severe limitations. The educational model was based on Active School principles. Moreover, workshops were organized in areas such as shoemaking, book binding and gardening. The concern for wholeness in the lives of the children can be noticed in the way the Institute was conceived, but also through the students' personal medical records.

\section{Medical Report Conduct}

Medical records are important sources to understand history. If, on the one hand, they are marked by the urgency of the moment of care and, in this sense, are not completely filled out, on the other hand, they bring the reality of a moment frozen in time. Pestalozzi Institute is currently a state school (Escola Estadual Pestalozzi), whose archives we visited.

The records are kept in a room, in boxes, filed in alphabetical order. There are records from the 1930s up to the present in those boxes. Each medical record was in a manila envelope. As said, we picked up a sample of records for the period 1933-1940. The content of the records varied a lot. Some bore a lot of data, others, very little. This difference can be due to the fact that many children assisted at the medical practice did not enroll at the Institute and did not go back for a follow-up. The medical records with more information were those of students enrolled at the Institute. Even though the Pestalozzi Institute only officially started its activities in 1935, the Medical-Pedagogical Station of the Pestalozzi Society of Minas Gerais (SPMG) had been opened since 1933.

The medical record presented belongs to a child who attended a special class, at a public school (medical record number E4 P170, year 1934, assisted in the Medical Pedagogical Station of SPMG). The boy was born in 1923, and was described as follows: drools a lot, difficulties with pronunciation, difficulty to pick up objects, walk and write. Today, this diagnosis would probably be cerebral palsy. The clinical history assessed by the physician was typed, which helped us understand this boy's history. The clinical history is completed with test results. The child is described as being very active in the group. He likes to study, learns easily and only had difficulties in writing. However, as contradictory as it might be, a piece of information says the boy had failed the 
school year twice. What makes a child who takes pleasure in school activities, learns with easiness, fail the year for the second time? His difficulties in writing? The medical-psychological history assessment continues and brings information on the results of intelligence tests. According to the Terman-Binet, his mental development reached 8 years and 11 months of age, which for the boy represented an IQ of 0.79 , as he was already 11 years old. He took all the tests at age 6 , at age 7 he could not copy the diamond shape, lacked visual-motor coordination, at age 8 he failed some requirements and at age 9 he was not able to organize boxes of different weights and didn't seem to notice the difference between the boxes. At age 10, he read part of a short story which was part of the test, remembering 8 details, with difficulties in pronouncing some words. Finally, at age 11, he was able to find the moral lesson of two fables.

Antipoff related the boy's failures to his poor motor skills and pronunciation. He showed more intellectual difficulties in the comparison test. He was not able to, for instance, to point out the existing analogy between a lime and an orange. At the test taken at age 10, he was not able to find the absurdities in the sentences. In the Proteus Maze test, which consists of exiting a maze, his motor difficulties were added to the difficulty of understanding the task. He was able to perform the test for the mental age of 5 years, failing the subsequent tests. He also showed low visual attention. His social intelligence, according to the person who applied the test, was hindered by the motor issues, as well as the intellectual impairment.

As mentioned before, the boy's motor skills were quite impaired. Curved legs, walking on his tiptoes, tripping several times, hands contracted inwards. He presented abrupt movements. Illegible writing as he was not able to coordinate his movements. Despite the disability, Antipoff stresses his qualities. Sociable, likes talking about politics, is persistent and smiles a lot. Sympathetic, he worries about others. Methodical and very frank, organized with his objects, he seems to be willing to work to overcome difficulties.

This description of the scenario already shows her sensitivity in understanding that, if on the one hand the child has difficulties, on the other hand he has potentialities. However, what drew out attention in the report is the suggestion for the child to use a typewriter. It was an innovative suggestion for the 1930s, using a resource that would allow the child to write, considering his difficulties that limited his writing.

Probably the victim of cerebral palsy, this child receives a guideline in 1934, when the term "assistive technology" did not exist yet. This term is currently used to denominate resources and services which might improve functional abilities of a disabled child. When Antipoff suggests that the child uses a typewriter, she opens up a new perspective, showing respect to the difference and uniqueness of that child. Writing is not necessary, whether printing or handwriting. Using a typewriter means to propose a change that reaches the school. It would be an anachronism to use the term inclusion for a fact which took place back in the 1930s, when the perspective of inclusion didn't even exist yet. Nevertheless, considering what is known today, we can perceive this attitude as being inclusive, as inclusion assumes that children with special needs can use the available resources to allow them the right to access education. There are clear limits related to the condition presented by the child. The psychologist presents a way to overcome this limit, whereas encouraging the child to work on his motor skills.

This case, found in the medical-psychological records, brings to light an innovative conduct. The respect for the uniqueness of the child is expressed in the suggestion to use the typewriter. Here, we can see that when a specific resource is proposed to cope with his difficulties in writing, a new perspective is opened to education when it comes to equal rights. In the 1930s, the child does have access to education, which is ensured by the implementation of the special classes. Moreover, the child is guaranteed permanence in the educational system, as his specific needs are respected. Special classes were innovated in the country, as they opened the doors to children who had been excluded from formal education. And the conduct adopted by Helena Antipoff in this case is the paradigm of the attitude of a group led by her, which promoted relevant advances in special education in Brazil.

\section{Final Considerations}

The proposal of special classes was already being implemented in European countries, as primary education became mandatory. The diversity of children attending schools drove researchers and technicians in the field of Education to propose alternatives to teach children who were not able to follow their classes. The first special class for children whose development was "impaired" or "retarded" was created in Switzerland in 1895, in Lausanne. A special class happens in Geneva in 1898, not as a solution to all problems, but as a solution among others. However, back then the special class seemed to be suitable because it validated a pedagogical idea that 
was starting to gain steam, the idea of educational methods which considered children's capabilities (Ruchat, 2003).

Helena Antipoff was not indifferent to the fact that tests selected children not considering their natural intelligence, but taking into account a type of intelligence moulded by the environment. Even so, she advocated for the use of tests, which could be used for a first selection. Teachers would then be responsible to assess the years following the performance of these tests to promote children. Thus, such selection would be temporary.

Back then, few children had access to the educational system. In 1878 there were 9 million inhabitants in Brazil and only 175 thousand of them were students. In 1890, 85\% of Brazilians were illiterate, considering all age groups (Januzzi, 1985). If access to education was limited to a great portion of the Brazilian population with no disability, then access to education by the disabled was extremely rare. Alvim (1967) argued that, before 1931 and the initiatives by the group led by Helena Antipoff, there was no work being done with these children. They were put in dark rooms with no specific work being done with them.

At a time when few children had access to education, even though education was mandatory, the arrival of disabled children at schools and their permanence in this environment were constantly threatened. Classrooms with fewer students, qualified teachers, differentiated classes, individual teaching: this was the ideal special class Antipoff intended to establish. Aintipoff believed that this specific teaching could promote the development of disable children. That being said, children needed to be classified to promote homogenization and allow for individualized teaching.

Children would enter a special class after tests were carried out. However, Antipoff found it vital to relativize the use of such tests. Antipoff believed children could develop along their school years. D classroom children could reach A classrooms through merit and development with no need to wait for the entire year to be transferred. Thus, intelligence could not be limited to the realm of natural competences. It is rather a complex product which involves the environment, the stimuli received by children and access to cultural goods. However, special classes would be necessary to assist children with true deficits. These classes would allow for individualized teaching.

Special classes allow access to education for a once marginalized population. Closed in their homes or with no specific methodology being used in schools to allow them to advance, these children remained invisible. Special classes, currently discussed deemed segregating, were important places for education during the time period studied. The establishment of these educational instruments allowed the beginning of the process which led to a better understanding of the specificities of disabled children, as well as of the need for special and curricular adaptations. When Helena Antipoff proposes the use of a typewriter, she signals toward the respect for individual differences and the belief that children once considered hopeless could be somehow educated.

\section{References}

Alvim, F. C. (1967). Introdução ao estudo da Deficiência Mental (Oligofrenias). Belo Horizonte: Imprensa Oficial. (Introduction to the Study of Mental Retardation (Oligofrenias). Belo Horizonte, Brazil: Official Publisher).

Antipoff, H. (1931). A pedagogia nas classes especiais (Pedagogy in Special Classrooms). Revista do Ensino, Belo Horizonte, Inspetoria Geral do Ensino, VI (56, 57, 58), 24-39.

Antipoff, H. (1944). Relatório da Primeira Diretoria da Sociedade Pestalozzi (1932-1935) apresentado à assembleia geral no dia 17 de março de 1935, pela sua presidente, professora Helena Antipoff. In: Coleção do Departamento Nacional da Criança (First Management Report of the Pestalozzi Society (1932-1935) Presented to the General Meeting on 17 March 1935 by Its President, Professor Helena Antipoff). In: National Children's Department Collection. Rio de Janeiro: National Press. (Original Published in 1935)

Antipoff, H. (1944a). Breve relatório da Sociedade Pestalozzi para o ano de 1936 e o primeiro trimestre de 1937. In: Coleção do Departamento Nacional da Criança. Rio de Janeiro: Imprensa Nacional (Brief Pestalozzi Society Report for the Year 1936 and the First Quarter of 1937. In: Collection of the National Children's Bureau. Rio de Janeiro: National Press). (Original Published in 1937)

Antipoff, H. (1992). Classes especiais "D" e "E"-Modo de formulá-las. In: CDPHA—Centro de Documentação e Pesquisa Helena Antipoff, Org. Coletânea das Obras Escritas de Helena Antipoff (Vol. 3: Educação dos Excepcionais, pp.47-48). Belo Horizonte: Imprensa Oficial. (Special classrooms "D" and "E"-How to Organize Them. Center for Research and Documentation Helena Antipoff, Org. Helena Antipoff's Collected Papers (Vol 3: Education of Exceptionals, pp. 47-48). Belo Horizonte, Brazil: Official Press). (Original Published in 1930)

Campos, R. H. F. (2001). Helena Antipoff (1892-1974): A Synthesis of Swiss and Soviet Psychology in the Contexto of Brazilian Education. History of Psychology, 4, 133-158. http://dx.doi.org/10.1037/1093-4510.4.2.133 
Campos, R. H. F. (2012). Helena Antipoff, psicóloga e educadora-Uma biografia intelectual (Helena Antipoff, Psychologist and Educator-An Intellectual Biography). Rio de Janeiro: Fundação Miguel de Cervantes.

Campos, R. H. F., Lourenço, E. and Antonini, I. G. (2002). Introdução-Helena Antipoff e a psicologia no Brasil (Introduction-Helena Antipoff and Psychology in Brazil). In: Campos, R. H. F. (Org.), Helena Antipoff: Textos Escolhidos (Helena Antipoff Collected Papers), (pp. 12-36). São Paulo/Brasília: Casa do Psicólogo/Conselho Federal de Psicologia.

Cirino, O. (1992). O descaminho daquele que desconhece (The Diversion of the One Who Knows). Fasciculos FHEMIG, 7 , 39-83.

Hofstetter, R., \& Schneuwly, B. (2009). New Education at the Heart of Knowledge Transformations. Paedagogica Historica, $45,230 \mathrm{p}$.

Januzzi, G. M. (1985). A Luta pela educação do deficiente mental no Brasil (The Crusade for the Education of the Mentally Deficient in Brazil). São Paulo: Cortez Editora.

Minas Gerais. (1933). Infância Excepcional (sub-normais). Boletim da Secretaria da Educação e Saúde Pública de Minas Gerais (Publicação a cargo da Sociedade Pestalozzi de Minas Gerais), n. 12. (Exceptional Childhood (sub-normals), Bulletin of the State of Minas Gerais Department of Education and Public Health, n. 12, Publication in Charge of the Pestalozzi Society of Minas Gerais).

Minas Gerais. (1934). Infância Excepcional (sub-normais). Boletim da Secretaria da Educação e Saúde Pública de Minas Gerais (Publicação a cargo da Sociedade Pestalozzi de Minas Gerais), n. 16. (Exceptional Childhood (sub-normals). Bulletin of the State of Minas Gerais Department of Education and Public Health, n. 16, Publication in Charge of the Pestalozzi Society of Minas Gerais).

Minas Gerais. (1937). Infância Excepcional (sub-normais). Boletim da Secretaria da Educação e Saúde Pública de Minas Gerais (publicação a cargo da Sociedade Pestalozzi de Minas Gerais), n. 20. (Exceptional Childhood (sub-normals). Bulletin of the State of Minas Gerais Department of Education and Public Health n. 20, Publication in Charge of the Pestalozzi Society of Minas Gerais).

Resende, N. (1934). Orientação do ensino nas classes especiaes dos grupos escolares de Belo Horizonte, em 1933. Boletim da Secretaria de Educação e Saúde Pública de Minas Gerais, Publicação a cargo da Sociedade Pestalozzi-A Infância Excepcional (sub-normaes e desamparados). (Teaching in Special Classes in Belo Horizonte Elementary Schools, 1933. Bulletin of the State Department of Education and Public Health, Publication in Charge of the Pestalozzi Society of Minas Gerais-Exceptional Childhood (Sub-Normal and Helpless Children), 16, 55-66.

Roca, J. (2012). La formation de maîtres spécialisés, un terrain d'expérimentationpour l'Éducation nouvelle 1930-1964 (The Training of Specialized Teachers, a Terrain for Experimentation for the New Education 1930-1964). In Gutierrez, L., Besse, L., \& Prost, A. (Eds.), Réformer l'école. L'apport de l'Éducationnouvelle (1930-1970) (Reforming Schools: The Contribution of the New Education Movement) (pp. 305-316). Grenoble: Presses universitaires de Grenoble.

Ruchat, M. (2003). Inventer les arriérés pour créer l'intelligence-L'arriéré scolaire et la classe spéciale. Histoire d'un concept et d'une innovation psychopédagogique (1874-1914). Bern: Peter Lang. (Inventing Retardation to Create Intelligence-School Retardation and Special Classrooms. History of a Concept and of a Psychoeducational Innovation (1874-1914). Bern: Peter Lang).

Samara, E. M., \& Tupy, I. S. S. T. (2007). História \& Documento e metodologia de pesquisa (History \& Document and Research Methodology). Belo Horizonte: Autêntica Editora.

Sociedade Pestalozzi. (1933). Assistência a menores em Minas Gerais. Boletim da Secretaria da Educação e Saúde Pública de Minas Gerais (publicação a cargo da Sociedade Pestalozzi) (Assisting Minors in Minas Gerais. Bulletin of the State Department of Education and Public Health, Publication in Charge of the Pestalozzi Society of Minas Gerais- Exceptional Childhood), 20, 47-51.

Van Drenth \& Myers, K. (2011). Normalising Childhood: Policies and Interventions Concerning Special Children in the United States and Europe (1900-1960). Paedagogica Historica-International Journal for the History of Education, 47, 719-727. 